\title{
"Segundo as leis da beleza": evolução e elevação em um soneto de Antero de Quental
}

Fecha de recepción: 28/5/2020. Fecha de aceptación: 24/10/2020.

\section{Resumo}

Neste artigo, analisamos o soneto "Evolução" (1886), do poeta português Antero de Quental, considerando o momento de sua produção, quando o tema da evolução não só já havia posto à prova sistemas filosóficos, postulados religiosos e convenções sociais, como já recebera uma interpretação político-filosófica que se tornara hegemônica na segunda metade do século XIX, o darwinismo social. Nessa configuração determinada, o soneto aqui analisado, assim como muitos outros da obra de Quental, parece caminhar na direção contrária a essa tendência naturalista. Investigamos aqui as razões para tal dissonância entre o poema e sua época, apostando na hipótese de que o tema da evolução, no soneto de Antero, é composto artisticamente "segundo as leis da beleza" (Marx, 2004) e, por essa razão, escapa do idealismo e do naturalismo, elevando a evolução a sua real dimensão histórica. 
"In accordance with the laws of beauty": elevation and evolution in a sonnet by Antero de Quental

\begin{abstract}
This study examines the sonnet "Evolução" (1886), wrote by the Portuguese poet Antero de Quental, in regards to the moment of its making, when the theme of evolution had not only pressured the philosophical systems, religious postulates and social conventions, but had already received a political-philosophical interpretation which would become hegemonic in the second half of the 19th Century: Social Darwinism. Seen within this determined configuration, this sonnet, as well as many others found in Quental's works, seems to take the opposite path of such naturalist tendency. Here we investigate the logic behind such dissonance between the poem and its time, focusing on the hypothesis that the theme of evolution in Antero's sonnet is artistically composed "in accordance with the laws of beauty" (Marx, 2004) and, therefore, escapes idealism and naturalism and, thus, elevates evolution to its real dimension in history.
\end{abstract}

Keywords: Antero de Quental; evolution; artistic elevation; historical and material production.

\title{
1. A temática da evolução e a literatura portuguesa na segunda metade do século XIX
}

O soneto "Evolução" foi escrito por Antero de Quental (1842-1891), provavelmente, entre 1880 e 1884 e publicado em 1886, na antologia Os sonetos completos de Antero de Quental, organizada e prefaciada por Oliveira Martins, amigo do poeta. O seu título evoca um tema que, no momento da composição do poema, não apenas assumira posição central nos debates científicos, filosóficos e artísticos inaugurados após a publicação de A origem das espécies (1859), de Charles Darwin, como também já havia, na esteira das polêmicas por ele provocadas, consolidado, entre as diferentes reverberações da teoria evolucionista, algumas tendências dominantes na sua interpretação, especialmente, a partir da década de 70, a do darwinismo social, que transpunha de modo imediato os parâmetros das ciências naturais relativos à evolução para a análise das sociedades humanas. Assim, na segunda metade do século XIX, houve uma verdadeira onda de cientificismo, na qual as correntes mais destacadas, além do darwinismo, o positivismo e o determinismo, realizavam uma espécie de transferência imediata das teorias científicas, isto é, das "Leis da Natureza", para a estrutura social.

Antes mesmo da publicação deste poema de Quental, que trata abertamente do tema da evolução, a literatura portuguesa já se via compelida a encarar essa questão que agitava tanto as discussões acadêmicas quanto a mentalidade do homem comum. Entre os textos que expressam claramente essa tendência ao darwinismo social na literatura portuguesa, está o romance folhetinesco As 
pupilas do Senhor Reitor, de Júlio Dinis, de 1866, que antepunha a ciência moderna anunciada pelo jovem médico Daniel à perspectiva conservadora, religiosa e ingênua do pequeno comerciante João da Esquina, habitante de uma aldeia portuguesa que se mostra assombrado quando o abastado lavrador José das Dornas, pai de Daniel, anuncia o que o filho, estudante de medicina na cidade do Porto, afirmara numa carta:

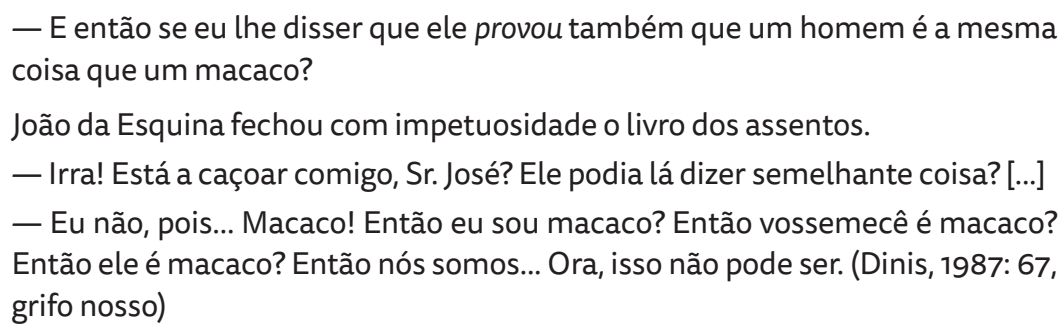

Também nas obras de Eça de Queirós, que juntamente com Antero de Quental participou das Conferências do Casino de Lisboa, além de compor o "Cenáculo", grupo de jovens intelectuais portugueses da geração de 70, o tema da evolução se apresenta tanto indiretamente nos romances da primeira fase $(O$ crime do padre Amaro, de 1875, e 0 primo Basílio, de 1878) quanto, de forma mais explícita, em contos produzidos pouco antes de sua morte em 1900 e publicados postumamente em 1902: "Adão e Eva no paraíso" (1897) e "O tesouro" (1894). No primeiro, a discussão sobre a evolução aparece explicitamente, mas em uma curiosa e irônica acomodação à perspectiva criacionista:

Assim ocupou o seu dia o Orango, nas árvores. E no entanto, como gastou, nas cidades, o seu dia o Homem, primo do Orango? Sofrendo - por ter os dons superiores que faltam ao Orango! Sofrendo - por arrastar consigo, irresgatavelmente, esse mal incurável que é a sua Alma! Sofrendo - porque nosso Pai Adão, no terrível dia 28 de outubro, depois de espreitar e farejar o Paraíso, não ousou declarar reverentemente ao Senhor: - "Obrigado, oh meu doce Criador; dá o governo da Terra a quem melhor escolheres, ao Elefante ou ao Canguru, que eu por mim, bem mais avisado, volto já para a minha árvore!" (Queirós, 1997a: 367)

No segundo conto, o narrador afirma que os personagens principais, "Os três irmãos de Medranhos, Rui, Guannes e Rostabal, eram então, em todo o Reino das Astúrias, os fidalgos mais famintos e os mais remendados", que, "fendendo a neve, iam dormir à estrebaria, para aproveitar o calor das três éguas lazarentas que, esfaimadas como eles, roíam as traves da manjedoura." E, anunciando o desfecho trágico do conto, em que os três irmãos acabam por se matarem uns aos outros, o narrador, já logo no início da narrativa, adverte que "a miséria tornara esses senhores mais bravios que lobos" (Queirós, 1997b: 315).

Seja no romance de Dinis, seja nos contos de Eça, o tema da evolução é alinhado, às vezes mais outras vezes menos, à lógica do darwinismo social. No romance, o antagonismo entre o ponto de vista científico e o popular gira em torno da justaposição imediata entre macaco e homem, reafirmando a descendência 
direta do segundo em relação ao primeiro, rechaçada pelo homem do campo e apresentada como prova científica pelo estudante de medicina da cidade grande. Em "Adão e Eva no paraíso", a conciliação entre criacionismo e evolucionismo resulta em efeito irônico que expressa ceticismo quanto ao desenvolvimento histórico da humanidade, reduzido a um fatalismo que dá crédito a um impossível passo para trás, involutivo ("volto já para a minha árvore!"), frente às contradições inerentes ao desenvolvimento humano, que, segundo o narrador do conto, porta voz do naturalismo do autor, está fadado à infelicidade, ao insucesso. No conto "O tesouro", a situação miserável dos três irmãos os condena a uma condição não humana ("mais bravios que lobos"), animalesca, que os conduz inexoravelmente, mesmo quando superada a miséria graças à descoberta de um tesouro, à destruição mútua dos irmãos, encenada no conto como uma disputa pelos dobrões de ouro empreendida pelo irmão que se mostra mais apto que os demais a sobreviver: Rui, o irmão do meio convence Rostabal, o mais velho, a assassinar o mais novo, Guannes, que não era forte o bastante para se adaptar à nova vida de abundância. Entretanto, ele acaba também destruído pela artimanha do irmão mais novo, que, antes de ser assassinado, envenenara a garrafa de vinho destinada a Rui. Dessa forma, aqui sumariamente referidas, as narrativas, relativamente contemporâneas ao poema "Evolução" de Antero de Quental, tratam essa questão no eixo comum e dominante na segunda metade do século XIX: o darwinismo social, deformação positivista e mecanicista das descobertas científicas de Darwin.

\section{Positivismo científico e antipositivismo filosófico em Antero de Quental}

O poema "Evolução", de Quental, no entanto, como pretendemos demonstrar aqui, parece ser avesso a essa compreensão a-histórica, determinista e estanque da evolução. Mas, antes de buscar entender por que razão Antero de Quental, ainda quando aborda claramente o tema da evolução, não o vincula à perspectiva determinista do naturalismo, mesmo estando ativamente inserido na agitação político-estética desse momento vivido pelos intelectuais portugueses, julgamos necessário expor brevemente a atuação desse poeta no seu tempo.

Como integrante da Geração de 70, que constituiu a produção da literatura portuguesa na segunda metade do século XIX, o poeta Antero de Quental esteve profundamente interessado e inserido na discussão que, àquele momento, procurava compreender e encaminhar soluções para as "Causas da Decadência dos Povos Peninsulares", tema desenvolvido por Antero de Quental no ciclo “Conferências Democráticas", no Cassino Lisbonense, em 1871. Essa geração de poetas, escritores e intelectuais portugueses se confrontava com a posição de Portugal no conjunto das nações e assumia declaradamente a condição de isolamento da nação portuguesa no panorama geopolítico do seu tempo; condição que esses intelectuais ambicionavam corrigir por meio de um projeto de reforma 
da sociedade portuguesa, cujo eixo estaria assentado, sobretudo, sobre a força emanada da renovação cultural. As intenções reformistas calcadas no plano da renovação literária e ideológica evidenciavam as ambições das estratégias traçadas pelos intelectuais portugueses para dar consequência às providências necessárias ao movimento capaz de pôr fim à inércia e ao isolamento que entrincheiravam a nação, impedindo-a de transpor as fronteiras do mundo civilizado, isto é, integrado ao influxo da modernidade:
Abrir uma tribuna onde tenham voz as ideias e os trabalhos que caracterizam esse movimento do século, preocupando-nos sobretudo com a transformação social, moral e política dos povos;
Ligar Portugal com o movimento moderno, fazendo-o assim nutrir-se dos elementos vitais de que vive a humanidade civilizada;
Procurar adquirir a consciência dos fatos que nos rodeiam na Europa;
Agitar na opinião pública as grandes questões da Filosofia e da Ciência moderna; Estudar as condições da transformação política, econômica e religiosa da sociedade portuguesa. (Quental, 2016:45.)

A lista de objetivos declinados por Quental expressa, a um só tempo: o reconhecimento claro da posição periférica do país nos diversos campos que o constituem (social, moral, político, econômico, cultural etc.); o desejo de promover mudanças efetivas na sociedade; e, ainda, o caráter cultural e ideológico da via escolhida para a renovação: "Agitar na opinião pública as grandes questões da Filosofia e da Ciência moderna”.

Para os intelectuais portugueses da Geração de 70, essa "Ciência moderna" era o "movimento do século" e o contraponto necessário ao caráter conservador do Estado português ainda fortemente atrelado ao clero, ao sistema econômico do país agrário, sem industrialização efetiva e sem uma burguesia forte, fatores que impediam, em Portugal, a evolução econômica ocorrida no resto da Europa e mantinham a nação economicamente dependente; tratava-se de "Ligar Portugal com o movimento moderno, fazendo-o assim nutrir-se dos elementos vitais de que vive a humanidade civilizada". A “Ciência moderna", nesse momento, está evidentemente associada às descobertas das ciências naturais, à teoria evolucionista e ao positivismo, que, na França, no terreno da arte, associam-se ao naturalismo de Zola, marcado pelo cientificismo e por uma visão determinista do caráter humano, mas também por uma atitude combativa e participante, como a assumida pelo autor de Germinal no célebre caso Dreyfus. Antero de Quental, movido por aspirações socialistas, em conflito com sua condição de proprietário, também teve uma significativa participação na vida social portuguesa, buscando parcerias com a classe operária, cooperando com a fundação da Associação Internacional dos Trabalhadores e produzindo folhetos de propaganda socialista. Antero de Quental, a despeito do confinamento do seu movimento intelectual ao campo da consciência, das ideias, dos trabalhos acadêmicos, do estudo e das grandes questões filosóficas e científicas, não assumiu uma postura intelectual desligada da vida social e política. Toda essa geração enfrentou como lhe foi possível a dura contradição imposta aos artistas pela realidade portuguesa no conjunto do desenvolvimento global do capitalismo. 
Quanto à "Filosofia”, é preciso ressaltar que, às atividades político-culturais de Antero, se junta a sua condição de filósofo, inicialmente ligado a Schopenhauer, e posteriormente um leitor apaixonado da obra de Hegel. Seu idealismo filosófico se funde e se mescla a uma dimensão metafísica que ora volta seu interesse para temas religiosos que deslizam entre o budismo, como em "Nirvana", e o cristianismo de "Na mão de Deus", ora produz uma atmosfera melancólica que anuncia, em tantos sonetos - como em "Oceano nox", "Palácio da ventura" e "Tormento do ideal" -, , o forte decadentismo que vigorará na poesia simbolista que lhe sucederá, com poetas finesseculares como Camilo Pessanha (1867-1926) e António Nobre (1867-1900). Em Antero de Quental, tal perspectiva filosófica decadentista e antipositivista dividia o espaço de seus escritos filosóficos, e também de sua poesia, com a dimensão positivista tributária da "Ciência moderna":

Se é verdade que Antero de Quental não foi um filósofo positivista, que cedo constatou os erros, as confusões, as lacunas e as incoerências do positivismo e mesmo que foi antipositivista no plano filosófico, não podemos omitir que teve forte simpatia por essa corrente de pensamento e a aceitou aplicada à ciência. Se éverdade que o homem maduro, de espírito independente, angustiado, ansioso de verdade, sofredor, sensível e crente, saturado do excesso de racionalismo, viu claramente a distinção entre a atitude científica positiva e o positivismo como doutrina filosófica, é também verdade que, não só, mas especialmente na fase mais juvenil e revolucionária do seu pensamento, rejubilou de entusiasmo com as espetaculares, para o seu tempo, descobertas e progressos científicos (...) Sobretudo nos primeiros escritos de Antero é constante essa sua posição prócientífica de acordo com o espírito da época (...). Assim, Antero foi positivista no plano da ciência e antipositivista no plano da filosofia (Brito, 1997: 40).

Essa coexistência entre positivismo científico e antipositivismo filosófico, típica de seus escritos filosóficos, imprimiu em sua poesia uma espécie de ambivalência entre protesto e resignação. Ao olhar, mesmo de forma panorâmica e breve, o percurso da vida e da obra de Antero e de seus contemporâneos da Geração de 70, é possível reconhecer como se expressaram e se desenvolveram essas tendências ao protesto e à resignação.

Esses escritores portugueses se iniciaram na literatura reunindo-se em um grupo chamado de "O cenáculo". O nome do grupo dos jovens autores dessa geração evocava a experiência vivida pelos discípulos de Cristo, que, escondidos por medo de que a perseguição sofrida pelo seu mestre recaísse sobre eles, receberam o batismo do espírito e, perdendo todo temor, saíram pelo mundo a pregar a boa nova. Entretanto, para os poetas da geração de 70, ao final de suas vidas, não houve boa nova para anunciar. Todos eles, "quando não aplacaram a luta das contradições interiores por meio da conversão ou do suicídio", como no caso de Antero, acabaram "na exaltação da vida campestre, da moral rústica ou das virtudes tradicionais" (Candido, 2006,

1 Os versos finais desses sonetos apontam invariavelmente para uma melancolia que estará ausente do soneto aqui analisado ("Evolução"): "Mas na imensa extensão, onde se esconde / O Inconsciente imortal, só me responde / Um bramido, um queixume, e nada mais..." ("Oceano nox"); "Abrem-se as portas d'ouro, com fragor... / Mas dentro encontro só, cheio de dor, / Silêncio e escuridão - e nada mais!" ("Palácio da ventura"); "Recebi o batismo dos poetas, / E assentado entre as formas incompletas, / Para sempre fiquei pálido e triste." ("Tormento do ideal"). Em: Judice, 2002, pp.27; 32, 45. 
p. 54). Os remanescentes do antigo "O cenáculo" compunham agora o grupo batizado de "Vencidos da vida", nome que "simboliza e encarna essa capitulação algo melancólica" (Candido, 2006, p. 54), anunciada já em muitos dos sonetos de Antero que, já morto, não integrava o segundo grupo, mas deixara, reunidos sobretudo em sua poesia, o embate entre protesto e a resignação do artista frente à decadência de Portugal em relação aos países centrais da Europa.

A posição fecundamente contraditória de Antero no interior dessa ambivalência histórico-estética de seu tempo talvez explique a não vinculação de sua poesia à perspectiva determinista do naturalismo de seus contemporâneos. Essas polaridades - positivismo científico e antipositivismo filosófico / protesto e resignação - entremeadas no conjunto da obra poética de Antero levaram a uma leitura crítica de sua poesia que afirmava a coexistência de vários Anteros. Assim, os diversos ciclos que a crítica atribui ao conjunto da obra de Antero de Quental acabam sempre reduzidos a uma duplicidade inquietante que opõe a poesia religiosa e metafísica à produção ligada ao novo ideário naturalista. Sem desconsiderar essa oposição, mas, justamente, a partir dela, é possível ler os sonetos anterianos como expressão de uma unidade contraditória, em que os elementos opositivos se confirmam mutuamente e se atritam em curto-circuito fecundo, delineando as fronteiras de um mundo em perspectiva diversa da realidade imediata que os seus contemporâneos da Geração de 70 tiveram dificuldades de compreender e formular. Dessa forma, os vários Anteros são um só, sem que a oposição entre a filosófica/metafísica e o ideário científico/material se desfaça. Logo, as diferenças entre poemas como "Evolução", “Oceano nox", "Na mão de Deus” ou "Nirvana" produzem um conjunto de tensões que compõem um mundo onde é possível que o chão histórico, com suas contradições, seja representado, mapeado esteticamente: o mundo da poesia.

\section{3. "Evolução" e as leis da beleza}

Em nossa hipótese é, sobretudo, a sua profunda adesão à poesia o que efetivamente impediu Antero, ao menos nos melhores momentos de sua produção, de conformar artisticamente a realidade de maneira deformadora, meramente naturalista ou puramente idealista. Sua devoção ao socialismo e aos trabalhadores, bem como à filosofia ou à metafísica e à espiritualidade, jamais se sobrepôs, em seu fazer poético, às exigências da própria poesia. Os temas sociais, filosóficos, metafísicos, espirituais e científicos, como o da evolução, são submetidos à medida da poesia e, não, o contrário. 0 mundo poético não se põe a serviço de ideias que o precedem, que são externas a ele. A poesia não se reduz a mural para exposição de teses, mas se realiza como mundo nascente, cujas raízes e bases parecem fincadas nele mesmo e não externamente. A criação desse mundo lírico, que gera a sensação de um mundo nascente, é que garante um efeito realista a partir da configuração lírica, pela qual tudo que é externo ao mundo do poema é internalizado pelo trabalho poético e transfigurado em matéria da poesia, tornando-se, assim, capaz de figurar o mundo exterior para além da imediaticidade 
já conhecida na vida cotidiana que dispensa a arte poética para ser alcançada. Se, para alcançar o imediato, não há necessidade de figuração artística, a poesia, por sua vez, é historicamente necessária ao desenvolvimento dos sentidos humanos, uma vez que dá uma dimensão nova ao mundo já conhecido e deixa ver nele o que, embora vivido, não foi ainda captado pela sensibilidade humana nem divisado pela consciência na experiência imediata.

O mundo poético que surge do ritmo e das imagens criadas pela atividade artística confere concretude à poesia de Antero, pois a recorrência à construção de um espaço poético, composto de elementos naturais e de outros construídos pelo homem, remete o leitor a referências locativas mais concretas e históricas, algo que se faz presente em muitos poemas de Antero de Quental, dando certo senso de real aos sonetos mais abstratos e filosóficos do autor. Em "Oceano nox", por exemplo, o eu lírico senta-se tristemente "Junto do mar". Em "Palácio da ventura", ao avistar o palácio em sua "pompa e aérea formosura”, o sujeito poético afirma: "com grandes golpes bato a porta e brado". Em "Tormento do ideal", Antero de Quental também cria um lugar poético a partir de referências locativas materiais que em tudo lembram particularidades concretas de Portugal - "serra, terra, mar, nau, torre" - e disputam o espaço do soneto com o discurso filosófico abstrato. Essa dinâmica compositiva, em que imagens poéticas trazem referências concretas exteriores para o interior do mundo poético enovelado em figurações abstratas, também atua no soneto objeto de nossa análise, elevando, pelo trabalho poético, o tema científico da evolução a sua real dimensão histórica, diferentemente do que lograram alcançar seus contemporâneos:

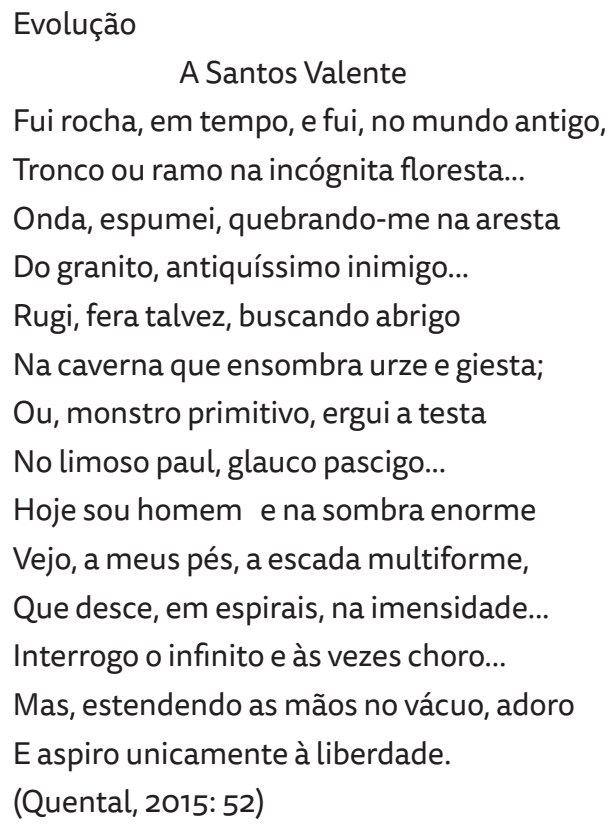

Especialmente nos dois quartetos do soneto, a poderosa configuração das imagens que emergem dos versos oferece ao leitor a ambiência necessária à construção de um mundo imagético marcado pela concretude: "fui rocha"; "fui (...) Tronco ou ramo na incógnita floresta"; "Onda (...) quebrando-me na aresta do 
granito"; "fera talvez"; "caverna que ensombra urze e giesta”; "monstro"; "testa". Do terreno poético, brotam imagens amplas e potentes que, dispostas em medida justa pelo ritmo dos versos nos quartetos, compõem cenas plenamente acessíveis à sensibilidade do leitor. Nos tercetos, embora a configuração das imagens expresse uma atmosfera abstrata e conceitual ("imensidade”; "infinito"; "vácuo"; "liberdade"), ligada ao estado de alma do eu lírico, ainda estão presentes as referências a um cenário ativo, não estanque nem decorativo ("sombra enorme"; "escada multiforme, que desce, em espirais"), dando maior concretude às ações do sujeito poético, todas elas realizadas no presente do mundo nascente no poema: "sou homem"; "vejo a meus pés"; "Interrogo o infinito e às vezes choro"; "estendendo as mãos no vácuo"; "adoro e aspiro unicamente à liberdade".

O eixo sobre o qual se estrutura o alicerce do soneto, seu princípio integrador, é a combinação entre essas referências espaciais concretas e a justaposição de dois tempos: o passado, demarcado nos dois quartetos pelos tempos verbais (verbos no pretérito perfeito do indicativo: fui, espumei, rugi, ergui) e pela adjetivação conferida ao "mundo" - "antigo" -,à "floresta" - "incógnita" -, ao "granito" - "antiquíssimo inimigo" -, e ao "monstro" - "primitivo" -; e o presente, vigente nos dois tercetos, conforme indicam os verbos no presente do indicativo referentes às ações do eu lírico enumeradas mais acima. A transição entre passado e presente é anunciada pelo verso final do segundo quarteto - "No limoso paul, glauco pascigo" - que estabelece fronteira com o presente do eu lírico que abre o primeiro terceto: "Hoje sou homem”. Além de estabelecer o limite/transição entre passado e presente, com o verso que encerra o segundo quarteto, o poeta envia o leitor até a cena em que o "monstro primitivo", pela primeira vez, levanta a cabeça ("ergui a testa"), sugerindo assim uma ampliação do horizonte da visão que passa a se dirigir, então, não mais para baixo, para o pântano ("limoso paul, glauco pascigo"), à procura de alimento. A elevação articula dois movimentos: o primeiro intensifica, pelo gesto do "monstro primitivo" levantando a cabeça, uma imagem concentrada do extenso processo evolutivo da espécie humana; o segundo decorre da composição estética pela qual a cena primitiva nos é apresentada com léxico poético clássico e refinado, que condensa em si a origem remota da própria lírica, fazendo lembrar a fala das musas a Hesíodo, quando pastoreava ovelhas ao pé do monte Hélicon, na Teogonia:

Esta palavra primeiro disseram-me as Deusas

Musas olimpíades, virgens de Zeus porta-égide:

"Pastores agrestes, vis infâmias e ventres só, sabemos muitas mentiras dizer símeis aos fatos e sabemos, se queremos, dar a ouvir revelações". Assim falaram as virgens do grande Zeus verídicas, por cetro deram-me um ramo, a um loureiro viçoso colhendo-o admirável, e inspiraram-me um canto divino para que eu glorie o futuro e o passado, impeliram-me a hinear o ser dos venturosos sempre vivos e a elas primeiro e por último sempre cantar. (Hesíodo, 1995: 88-89) 
A palavra das musas a Hesíodo afirma, na dimensão artístico-mitológica do mundo grego, a grandeza transcendente das habitantes do lendário monte Hélicon frente à pequenez imanente dos homens comuns, submetidos à luta pela sobrevivência na produção material de seu sustento: "Pastores agrestes, vis infâmias e ventres só". Entretanto, o resultado do encontro de Hesíodo com as musas, ${ }^{2}$ dentre elas as da Poesia, é também a elevação do pastor a aedo, sinalizada tanto pelo "cetro", feito de um ramo de um "loureiro viçoso", a ele conferido pelas musas, quanto pelo "canto divino" inspirado pelas deusas para que o aedo "glorie o futuro e o passado" e seja impelido a "elas primeiro e por último sempre cantar". Da necessidade, imposta pela vida agreste dedicada apenas ao ventre, o pastor adentra, pela poesia, no reino da liberdade; como aedo, seu trabalho é, agora, não mais pastorear ovelhas, mas "hinear o ser dos venturosos sempre vivos", isto é, cantar a memória, a mãe de todas as musas (Mnemosine), o que faz da arte memória da humanidade (passado) e, ao mesmo tempo, anúncio de um devir possível (futuro).

A elevação do pastor a aedo que é narrada na Teogonia se refere simultaneamente ao passado e ao futuro. Por um lado, está circunscrita à sociedade grega e ao lugar que o aedo desempenha nela, pois, graças ao "prazer elevado" que seu canto produz, "os aedos gozam de grande prestígio social"; "trazem sempre um conhecimento verdadeiro de acontecimentos passados"; e, "por fim, geram o efeito de arrebatamento da sensibilidade" (Cotrim, 2015: 194). Por outro lado, a elevação do pastor a aedo também anuncia a necessidade de que, na poesia, a subjetividade do poeta, embora não deixe de existir, seja também ela matéria do trabalho poético, isto é, esteja também ela submetida ao trabalho livre e criador,e, portanto, pronta a se tornar arte poética, capaz de elevar-se a uma subjetividade estética, ampla o suficiente para que leitores diversos possam se reconhecer nela como parte do gênero humano. É precisamente assim que as ações do eu lírico se transfiguram em ações do gênero humano: "Hoje sou homem", que vê, interroga, chora, estende as mão no vácuo, adora e aspira à liberdade. Nessa dimensão poética, a "Evolução" que dá título e matéria ao soneto de Antero não se apresenta ao leitor como um conceito científico-filosófico, nem como uma tese ou ideia abstrata, ela toma a forma do desenvolvimento humano, cujo longo processo é concentrado na figuração do eu poético elevado à generidade ("Fui rocha", "tronco ou ramo", "onda", "fera”, "monstro primitivo", "Hoje sou homem") e intensificado nos catorze versos do soneto - forma clássica e longeva -, ela mesma também uma escolha formal perfeitamente justa à necessária articulação entre passadopresente-futuro que a ação criadora da lírica põe em movimento.

O saber das musas, transmitido ao aedo como "canto divino", se liga a leis específicas da poesia - aqui por nós associadas às "leis da beleza" (Marx apud Frederico, 2013: 44) $-{ }^{3}$ que ainda hoje se mostram válidas. Na Teogonia, a primeira delas

2 Filhas de Zeus e Mnemosine, as nove musas que habitam o monte Hélicon são: Calíope (deusa da Poesia Épica); Clio (deusa da História); Erato (deusa da Poesia lírica); Euterpe (deusa da Música); Melpômene (deusa da Tragédia); Polímnia (deusa da Poesia Sagrada - Hinos); Terpsícore (deusa da Dança); Tália (deusa da Comédia) e Urânia (deusa da Astronomia), segundo Dicionário de Mitologia Grega e Romana, de Pierre Grimal (1997: 319-320).

3 Para as citações referentes a essa passagem dos Manuscritos econômico-filosóficos (de 1844) ou Manuscritos 
- "sabemos muitas mentiras dizer símeis aos fatos e sabemos, se queremos, dar a ouvir revelações" - diz respeito à natureza oblíqua da palavra poética, sempre em movimento entre a realidade e o reflexo artístico dela, capaz de dar forma à unidade contraditória entre o dito, os fatos e a real e profunda compreensão deles. Essa unidade contraditória refletida na arte nunca é uma simples cópia imediata do real, pois a dialética interna entre o cantado e o factual, ao produzir mentiras "símeis aos fatos", reúne as aparências dos fatos à essência deles, para, assim, dar "a ouvir revelações".

A segunda lei, "e a elas [musas] primeiro e por último sempre cantar", expressa uma exigência das musas, que, longe de ser um capricho de deidades mitológicas, é, ainda hoje, condição para que a dimensão do trabalho livre possa se fazer presente na arte; o mundo exterior precisa ser transformado em poesia para ressurgir como mundo nascente aos olhos do leitor. Paradoxalmente, já sabiam os gregos, a poesia, para alcançar a variedade extensiva da vida, não pode apenas reproduzir estritamente o mundo externo a ela, pois "não é função do poeta narrar o que aconteceu, mas, sim, o que poderia acontecer" (Aristóteles, 1986: 126). Só assim, é possível "gloriar o futuro", isto é, descobrir (no sentido de encontrar o que já existe, mas que estava encoberto) as possibilidades latentes na realidade que só os homens podem desenvolver.

A validade desse saber nos dias atuais não se explica pelo ângulo da atemporalidade a-histórica, mas está relacionada à concepção de história como uma totalidade, uma unidade do diverso, um processo que, embora extremamente contraditório, tem uma direção no sentido da busca do desenvolvimento da humanidade, da superação das barreiras naturais e sociais impostas à emancipação e à liberdade dos seres humanos, mas tal direção jamais se desenvolve de forma linear e etapista, idealista ou naturalista. Toda produção material desse processo histórico se realiza de maneira desigual e o próprio desenvolvimento das formas artísticas dá testemunho de que a "história universal não existiu sempre; a história considerada como história universal é um resultado." (Marx, 1974: 129.). Mas resultado de quê? Como afirmam Marx e Engels, em sua crítica satírica ao idealismo dos jovens hegelianos, a história é resultado das ações dos seres humanos entre si e em interação com o mundo circundante:

\footnotetext{
A História não faz nada, "não possui nenhuma riqueza imensa", "não luta nenhum tipo de luta"! Quem faz tudo isso, quem possui e luta é, muito antes, o homem, o homem real, que vive; não é, por certo, a "História", que utiliza o homem como meio para alcançar seus fins - como se se tratasse de uma pessoa à parte -, pois a História não é senão a atividade do homem que persegue seus objetivos (Marx; Engels, 2011: 122)
}

de Paris, de Karl Marx, apesar de consultarmos as traduções para o português nas edições da Boitempo (2004), tradução de Jesus Ranieri, e da Expressão Popular (2015), tradução lusitana de Maria Antónia Pacheco, optamos por citar a tradução apresentada no livro de Celso Frederico (2013), A arte no mundo dos homens. O itinerário de Lukács, baseada na edição dos Manuscritos de Paris. Em Marx; Engels. (1980). OME 5/Obras de Marxy Engels. Tradução de Manuel Sacristán. Barcelona, Grijalbo, p. 355 
A história não é, portanto, uma entidade metafísica, e seu andamento não pode ser resultado de um projeto mental, como propugnavam os jovens hegelianos em 1845, ano da publicação de A sagrada família ou A crítica da crítica crítica contra Bruno Bauer e consortes, de Marx e Engels (2011). Em outras circunstâncias e proporções, diante da estagnação nacional, os jovens intelectuais portugueses da geração de 70 - entre eles Antero de Quental, inspirado por forte proudhonismo - também defendiam um programa baseado na renovação cultural e na adoção dos ideais liberais que acenavam para o progresso da Europa mais adiantada. Se o programa ideológico da Geração de 70, por seu idealismo, esbarrou em seus próprios limites e não pôde perceber que é impossível transformar a realidade atrasada de Portugal apenas no terreno das ideias, paradoxalmente, a produção estética, especificamente a de Antero de Quental, escapa desse idealismo dominante ao aderir, na prática poética, às exigências da poesia - às leis da beleza -, historicamente construídas no fazer artístico em sua relação dinâmica com as contingências concretas, ou seja, no âmbito das ações humanas. Entretanto, se o mundo dos homens existe para além das ideias e da consciência acerca dele, o mundo poético que nasce, a partir das leis específicas da poesia, como reflexo estético de um mundo sempre em movimento, só se sustenta como artístico quando, como afirma Lukács (1982), "consegue superar a estreiteza de uma perspectiva ideológica determinada" e se eleva "acima dos condicionamentos históricos e de classe para expressar uma vox humana identificada com a essência genérica da humanidade" (Vedda, 2003: 27-28, grifos do autor, tradução nossa).

Essa generidade que fundamenta o texto poético é também responsável pela permanência de sua vitalidade ao longo do desenvolvimento da história da humanidade e, no interior dela, da história do desenvolvimento da própria literatura. O caráter dinâmico e contraditório da história se faz visível na produção das próprias obras de arte, pois é plenamente possível que grandes obras da humanidade sejam produzidas em momentos mais atrasados do desenvolvimento social. Marx sublinha esse desenvolvimento desigual entre a produção artística e a produção material de um determinado momento histórico ao analisar a permanência da importância e do interesse da Ilíada e da Odisseia em um período da história já tão distante daquele em que a épica homérica foi produzida. Isso, além de indicar o quanto a relação entre produção artística e produção econômica está distante de uma perspectiva mecanicista e determinista, evidencia que é exatamente a expressão da essência genérica da humanidade nessas obras que faz delas não só objeto de interesse de leitores ao longo dos séculos, mas que ainda se apresentem para eles como modelos estéticos insuperáveis:

A partir da íntima vinculação com a essência genérica da humanidade se explica que - tal como assinala corretamente o velho Lukács, em plena concordância com o pensamento de Marx -, ao se aproximar das maiores obras literárias e artísticas do passado, o homem atual sinta que se defronta com mundos que, para além da irrevogável distância temporal, são o seu próprio mundo; e possa, legitimamente, afirmar: mea res agitur. Neste ponto percebe-se a eficácia desfetichizadora da arte, sua capacidade para elevar-se acima das estruturas de pensamento e experiência coisificadas da vida corrente [...] Marx considera que 
[...], no epos homérico, o homem moderno pode encontrar uma representação consumada do passado da própria espécie; em termos lukácsianos, afirma, diante da épica antiga: nostra res agitur (Vedda, 2003: 31-32, grifos do autor, tradução nossa)

Ao alcançar essa generidade, a poesia se eleva acima das limitações históricas e classistas para expressar a essência genérica dos seres humanos (Vedda, 2003: 31). Isso mostra, mais uma vez, que as relações entre a arte poética e a realidade não são meramente causais ou determinadas de forma mecânica pela economia e pela posição de classe do poeta, como podem fazer crer as interpretações sociológicas imediatistas e positivistas da literatura. As relações entre arte e vida são bem mais dinâmicas, vivas e profundas; elas se baseiam nas leis específicas da poesia - "as leis da beleza" - que consistem em produzir de acordo com a medida dos objetos e se constituem historicamente como processo de afirmação e desenvolvimento da humanização do homem:

\section{O animal não conhece outra medida e necessidade senão a da espécie a que pertence, enquanto que o homem sabe produzir com a medida de qualquer espécie e aplicar em cada caso um critério imanente ao objeto; daí que o homem modele segundo as leis da beleza (Marx apud Frederico, 2013: 44, grifos nossos)}

Esse processo criador que transforma a objetividade circundante em um mundo social e humano exige, como critério primeiro, a atenção apaixonada e fiel à imanência do objeto mesmo. Somente com a apreensão mais acurada do ser dos objetos é possível reproduzi-los, transformá-los à medida das necessidades humanas, mas também superá-los a partir de uma produção autenticamente humana, pela qual as capacidades essenciais dos seres humanos se elevam para além da individualidade para expressarem a essência genérica da humanidade: "A produção prática de um mundo objetivo, a elaboração da natureza inorgânica é a confirmação do homem como consciente ser específico, isto é, como um ser que vê na espécie seu próprio ser e em si a espécie" (Marx apud Frederico, 2013: 44 , grifos nossos). A produção artística, que dá aos objetos um modo de existir ainda inédito, livre da necessidade física imediata da sobrevivência, suspendendo temporariamente sua utilidade e suas finalidades práticas, é, assim, a afirmação das bases ontológicas do trabalho livre e da humanização do homem, pois, ao contrário do animal, que "produz somente sob o império da imediata necessidade física", o homem, por sua vez, "produz mesmo sem ela e, até que se tenha libertado da necessidade física, não começa a produzir verdadeiramente" (Marx apud Frederico, 2013: 44, grifos nossos).

No soneto de Antero, o tema da evolução, modelado segundo as leis da beleza, é mimeses da humanização da natureza e, nesse sentido, vai na direção da elevação ("ergui a testa") do homem natural ao homem social, de toda natureza à natureza humanizada. Essa elevação poética é oposta à animalização do homem, que vigorava naquele momento alinhado à visão determinista do darwinismo social. A figuração do passado nos quartetos não diz apenas da origem da vida, ou, como diz o eu lírico do soneto, do que o homem foi um dia - "rocha", "tronco ou ramo", “onda”, “fera”, "monstro primitivo"; tal figuração diz mais, pois é feita a 
partir da construção de imagens poéticas que ressaltam o trabalho criativo e livre que nenhum animal pode efetivamente realizar, já que "o animal não conhece outra medida e necessidade senão a da espécie a que pertence, enquanto que o homem sabe produzir com a medida de qualquer espécie" (Marx apud Frederico, 2013: 44, grifos nossos). 0 poeta figura o processo evolutivo transcorrido sob o ângulo do presente, invertendo a lógica mecanicista e linear para alcançar a dinâmica da história e da produção poética, em que o passado emerge e se eleva, por meio das leis da beleza, a um mundo que pode ser reconhecido pelo leitor como mundo humano, como conhecimento verdadeiro, como forma acessível à sensibilidade do leitor de hoje (“Hoje sou homem”).

\section{Elevação artística e real dimensão histórica de "Evolução"}

O movimento que impele e eleva o soneto de Antero de Quental a mundo sensível e apreensível pelo leitor parece alinhado àquele que é feito por Marx, em 1857, ${ }^{4}$ ao analisar a produção material na sociedade burguesa moderna. Vejamos.

Na direção oposta à dos economistas clássicos (Smith e Ricardo) que veem nas robinsonadas - em que um homem civilizado é "transportado por acaso para um lugar selvagem, mas levando consigo já, dinamicamente, as forças da sociedade" (Marx, 1974: 110) - "uma simples reação contra os excessos de requinte e um retorno mal compreendido a uma vida natural", Marx vê "nas pequenas e grandes robinsonadas", assim como no Contrato social de Rousseau, "uma antecipação da 'sociedade' [...] da livre concorrência”, isto é, a sociedade burguesa, na qual o "indivíduo aparece desprendido dos laços naturais que, em épocas históricas remotas, fizeram dele um acessório de um conglomerado humano limitado e determinado" (Marx, 1974: 109). Os economistas do século XVIII partiam do pressuposto ilusório de que esse homem isolado seria "um ideal, que teria existido no passado", não "um resultado histórico, mas um ponto de partida da História" "um indivíduo conforme à natureza [...], que não se originou historicamente, mas foi posto como tal pela natureza" (Marx, 1974: 109-110). Entretanto, como ressalta Marx, “a época que produz este ponto de vista, o do indivíduo isolado, é precisamente aquela na qual as relações sociais alcançaram o mais alto grau de desenvolvimento", tanto que permitiram ao homem ser literalmente "um zoon politikon, não só animal social, mas animal que só pode isolar-se em sociedade" (Marx, 1974: 110). Dizendo de outro modo: "a sociedade burguesa, altamente complexa e sofisticada, na qual os indivíduos

4 Trata-se da Introdução escrita por Marx entre agosto e setembro de 1857. Conforme esclarecem os tradutores em nota apresentada na edição por nós consultada: "Com essa Introdução, Marx inicia seus apontamentos econômicos dos anos de 1857 a 1858, que foram publicados em conjunto em 1939, em Moscou, sob o título de Grundrisse der Kritik der politischen Ökonomie (Rohentwurf). Foi descoberta em 1902 entre os manuscritos deixados por Marx, e publicada pela primeira vez por Kautsky, na revista 'Die Neue Zeit' em 1903. É a esta Introdução que Marx faz alusão em seu prefácio de Para a Crítica da Economia Política. O título 'Introdução à crítica da economia política' não é do seu próprio autor, mas refere-se ao nome com que foi publicada a primeira vez e se tornou tradicional. O texto não foi preparado para a publicação e Marx se refere a ele como esboço (veja o referido prefácio)". Giannotti; Malagodi. Em Marx, Karl. (1974). Manuscritos econômico-filosóficos e outros textos escolhidos. Seleção de José Arthur Giannotti. Tradução de José Arthur Giannotti e Edgar Malagodi. São Paulo, Abril Cultural, p. 109. 
são interdependentes em virtude das leis de mercado, alimenta, de maneira paradoxal, a fantasia de que o indivíduo está, no começo, em realidade, sozinho" (Koval; Lenga, 2018: 170).

Essa contradição no interior do desenvolvimento da sociedade burguesa do século XVIII se estende para a compreensão acerca da produção material na "mais moderna Economia", no século XIX, quando o conjunto complexo de determinações divergentes da produção em geral é ignorado pelos economistas modernos, tendo por base os elementos comuns da produção entre épocas mais antigas e a mais moderna. Os economistas do século XIX se esquecem do fato de que "se as linguagens mais desenvolvidas têm leis e determinações comuns às menos desenvolvidas, o que constitui o seu desenvolvimento é o que as diferencia destes elementos gerais e comuns" (Marx, 1974: 111, grifo nosso). 0 esquecimento dessa diferença produz como resultado equivocado a naturalização do capital, entendido como "uma relação natural, universal e eterna" (Marx, 1974: 111). Assim, relações sociais envolvidas na produção material, que são determinadas historicamente, parecem ser regidas "por leis naturais, eternas, independentes da História; e nessa oportunidade insinuam-se dissimuladamente relações burguesas como leis naturais, imutáveis da sociedade in abstrato" (Marx, 1974: 112, grifos do autor).

Se é verdade que a "Economia burguesa fornece a chave da Economia da Antiguidade, etc.", na medida em que, a partir da compreensão das relações de produção que ela articula, é possível "penetrar na articulação e nas relações de produção de todas as formas de sociedade desaparecidas, sobre cujas ruínas e elementos se acha edificada", não é possível concordar, por isso, com o método dos economistas modernos, "que fazem desaparecer todas as diferenças históricas e veem a forma burguesa em todas as formas de sociedade" (Marx, 1974: 126). Trata-se de uma expressão da lógica burguesa decadente que, não só absorve o passado, mas também cancela qualquer horizonte de futuro para além da produção capitalista e da sociedade burguesa; lógica que é celebrada pelos apologistas e recebida como destino fatal, ainda que de forma crítica e aguda, tanto por idealistas quanto por naturalistas. Se no terreno da produção material tal método é falacioso, na produção artística, na qual, como vimos, se abre espaço para um desenvolvimento desigual entre arte e sociedade, esse método se mostra nocivo, pois submete a criação artística, não às leis da beleza, produzidas de forma livre e variada (com a medida de qualquer espécie e em cada caso com um critério imanente ao objeto), mas às leis rígidas e uniformes da sociedade burguesa já decadente; leis que buscam repetir um presente determinado ad infinitum, no passado e no futuro, como se fossem leis naturais, imutáveis. Na crítica ao método dos economistas modernos às formas da Economia burguesa, encontramos uma conhecida formulação de Marx que sugere um entendimento do tema da evolução em um sentido dissonante daquele que regia a perspectiva idealista e naturalista da questão: "A anatomia do homem é a chave da anatomia do macaco. $O$ que nas espécies animais inferiores indica uma forma superior não pode, ao contrário, ser compreendido senão quando se conhece a forma superior" (Marx, 1974: 126). 
Como vimos, a Economia burguesa contém elementos comuns à Economia da Antiguidade, mas pode explicá-la exatamente porque se diferencia dela, na medida em que se trata de uma forma mais desenvolvida e, portanto, não identificada às formas anteriores sobre as quais se elevou a ponto de tornar-se diversa e superior, "desenvolvendo tudo que fora antes apenas indicado [e] que toma assim toda a sua significação" (Marx, 1974: 126). Assim também, no que diz respeito à evolução, Marx afirma o caráter dinâmico e histórico do processo evolutivo e sublinha a elevação do homem, como espécie animal superior. Se as espécies inferiores ou menos desenvolvidas contêm elementos da forma superior, tais elementos só podem ser descobertos quando já está desenvolvida a forma superior: portanto, não é o macaco que explica o homem, mas o homem que explica o macaco.

O método dos economistas modernos de entendimento da Economia moderna era ilusório e deformava o objeto estudado, na medida em que, esquecendo as diferenças entre as formas antigas e a moderna, naturalizava e tornava lei eterna um momento determinado da história, que, assim, se transformava na História inteira, não deixando espaço para a evolução/elevação das formas a partir do enfrentamento das contradições próprias do desenvolvimento. 0 método idealista e/ou naturalista de compreender a teoria da evolução também elide a diferença entre macaco e homem em favor da semelhança entre ambos, afirmando, assim, uma perspectiva mítica e ao mesmo tempo determinista, como a que vemos no conto "Adão e Eva no paraíso", de Eça de Queirós, que, citado no início deste texto, associa, sem conflitos, criacionismo e evolucionismo e expressa como mensagem central um profundo pessimismo em relação ao desenvolvimento do "bicho homem", que jamais deveria ter descido das árvores ou erguido a testa para um horizonte além da sobrevivência imediata.

O soneto de Antero nos parece alinhado a esse processo analisado por Marx e aqui exposto sumariamente, porque na sua composição o tema da evolução se apresenta articulado à sua real dimensão histórica. Com isso não queremos afirmar uma filiação político-filosófica consciente e voluntária do poeta a essa crítica de Marx aos economistas e filósofos modernos. Ao contrário, Antero de Quental partilhava conscientemente dos ideais utópicos de Proudhon, de quem Marx divergia irônica e veementemente exatamente quanto ao seu método histórico-filosófico para deduzir a origem das relações econômicas, que lhe permitia "o recurso à mitologia, e dizer que as ideias surgiram de modo acabado na mente de Adão ou Prometeu, e postas em uso. Nada é mais aborrecedor e árido do que o locus communis (lugar-comum) disfarçado" (Marx, 1974: 110). Embora o idealismo proudhoniano injete fortes elementos filosóficos em seus poemas, na maioria das vezes, como no caso de "Evolução", ainda que, especialmente no último terceto, seja possível perceber influxos idealistas, a poesia eleva-se sobre os elementos filosóficos e o cientificismo naturalista, por meio de diferentes expedientes estéticos, entre eles o de criar um mundo ante os olhos do leitor a partir da construção de espaços poéticos concretos. Além disso, sua adesão às leis da beleza, sua atenção artística às leis impostas pelo objeto do poema, faz com que a dimensão histórica de "Evolução" lateje nos versos do soneto. 0 passado e 
o presente se vinculam no ritmo, nas imagens, nas medidas e na composição do conjunto, mas também se separam e delineiam os contornos entre o que foi "no mundo antigo" e sua evolução no "Hoje" do poema. $\mathrm{O}$ eu poético que fala e age não é um homem ideal abstrato e tampouco o protótipo do indivíduo isolado e fragmentado, mas um eu vinculado ao gênero humano e consciente da odisseia humana. No jogo poético do tempo no soneto, passado e futuro se compõem como formas em movimento, mutáveis: o que era "primitivo" pode erguer a testa e avançar; o futuro não é determinista e inflexível, ainda está por ser feito pela ação humana: "estendendo as mãos no vácuo, adoro e aspiro unicamente à liberdade". A vida cotidiana, o locus communis, o tema filosófico-científico da evolução não é disfarçado, mas, antes, elevado. Como produção artística, o soneto de Antero deixa evidente o caráter ontológico, não-linear, dinâmico e desigual da produção; tanto da produção material em geral, quanto da produção do próprio homem, bem como da produção artística.

Em épocas antigas, cujo desenvolvimento social e econômico foi inferior ao da Economia moderna, foi possível a produção de obras nas quais os homens ainda hoje podem reencontrar seu próprio mundo, tanto como um momento da humanidade em sua evolução, quanto como um anúncio das possibilidades de um futuro que não se limite a reprodução infinita do presente. Em razão dessa forma da produção artística, que buscamos sublinhar ao longo deste texto, a arte pode elevar - na epopeia, no romance, ou mesmo no pequeno mundo do soneto "Evolução" - a vida cotidiana e restabelecer o vínculo, esmaecido na sociedade burguesa, entre o indivíduo isolado, fragmentado e a espécie a que pertence: o gênero humano. Dessa forma, a elevação do cotidiano alienado, realizada no mundo da arte, nunca "é uma fuga, um devaneio inconsequente", pois,

Após a fruição estética, o homem mobilizado pela arte volta a defrontar-se com a fragmentação do cotidiano. [...] A arte, portanto, educa o homem fazendo-o transcender a fragmentação produzida pelo fetichismo da sociedade mercantil. Nascida para refletir sobre a vida cotidiana dos homens, a arte produz uma "elevação" que a separa inicialmente do cotidiano para, no final, fazer a operação de retorno" (Frederico, 2000: 305, grifo do autor). 


\section{Bibliografia}

" Aristóteles. (1986). Poética. Tradução, Prefácio, Introdução, Comentário e Apêndice de Eudoro de Souza. Lisboa, Imprensa Nacional; Casa da Moeda.

" Candido, A. (2006). "Entre campo e cidade". In: Tese e antítese. Rio de Janeiro: Ouro sobre Azul, pp.39-59.

"Cotrim, A. A. (2015). Contribuições de Karl Marx ao problema da mimese artística. Tese de Doutorado. São Paulo, Faculdade de Filosofia, Letras e Ciências Humanas, Universidade de São Paulo.

"Dinis, J. (1987). As pupilas do Senhor Reitor. São Paulo, Editora Ática.

"Frederico, C. (2013). A arte no mundo dos homens. O itinerário de Lukács. São Paulo, Expressão Popular.

"Frederico, C. (2000). Cotidiano e arte em Lukács. Em Estudos Avançados. v.14, no 40. São Paulo, USP, pp. 299-308.

" Grimal, P. (1997) Dicionário da mitologia grega e romana. Trad. de Victor Jabouille. $3^{\underline{a}}$ ed. Rio de Janeiro, Bertrand Brasil.

" Hesíodo. (1995). Teogonia. A origem dos deuses. Estudo e Trad. de Jaa Torrano. São Paulo, Iluminuras.

" Júdice, N. (2002). Antero de Quental - Sonetos. Lisboa: Imprensa Nacional - Casa da Moeda.

"Koval, M; Lenga, J. (2018). Lukács y las robinsonadas del siglo XVIII: la laboriosidad como atributo de la burguesía triunfante. Em Corrêa, Ana Laura dos Reis; Cotrim, Ana Aguiar; Koval, Martín Ignácio (ed.). Cerrados. Dossiê "Marx: Arte, Literatura e Práxis". Brasília, n. 47, pp. 168-185.

"Lukács, G. (2010). Marxismo e Teoria da Literatura. Seleção, apresentação e trad. de Carlos Nelson Coutinho. 2a edição. São Paulo, Expressão Popular.

"Lukács, G. (1982). Estética 1. La peculiaridad de lo estético. Trad. de Manuel Sacristán. Barcelona, Grijalbo, v.2.

" Marx, K. (2015). Cadernos de Paris \& Manuscritos econômico-filosóficos de 1844. Trad. de José Paulo Netto e Maria Antónia Pacheco. São Paulo, Expressão Popular.

" Marx, K. (2004). Manuscritos econômico-filosóficos. Tradução, Apresentação e Notas de Jesus Ranieri. São Paulo, Boitempo.

"Marx, K. (1997). 018 Brumário e Cartas a Kugelmann. Rio de Janeiro, Paz e Terra.

"Marx, K. (1974). Introdução à crítica da economia política. Em Manuscritos econômicofilosóficos e outros textos escolhidos. Seleção de José Arthur Giannotti. Trad. de José Arthur Giannotti e Edgar Malagodi. São Paulo, Abril Cultural, pp. 107-131.

" Marx, K.; Engels, F. (2011). A sagrada família ou A crítica da crítica crítica contra Bruno Bauer e consortes. Trad. de Marcelo Backes. São Paulo, Boitempo.

"Queirós, E. de (1997a). Adão e Eva no paraíso. Obras completas. Vol. II. Rio de Janeiro, Ed. Nova Aguilar, pp. 345-367.

"Queirós, E. de (1997b). O tesouro. Obras completas. Vol. II. Rio de Janeiro, Ed. Nova Aguilar, pp. 315-321. 
"Quental, A. (2016). Causas da decadência dos povos peninsulares. Rio de Janeiro, Tinta-da-china.

"Quental, A. (2015). Antero de Quental. Melhores poemas. Seleção e Prefácio de Benjamim Abdalla Júnior. São Paulo, Global Editora.

"Vedda, M. (2003). Introducción. Marx y Engels como teóricos y críticos de la literatura. Em Marx, K. y Engels, F. Escritos sobre literatura. Selección e Introducción de M. Vedda, pp. 7-41. Buenos Aires, Colihue.

" Brito, M. A. de Araújo Silveira de. (1997). O positivismo científico de Antero de Quental. Em Revista Portuguesa de Filosofia. T. 53, Fasc. 1, pp. 39-62. 